\title{
PENGALAMAN BERWIRAUSAHA BERBASIS MEMBACA ONLINE DI KALANGAN IBU RUMAH TANGGA
}

\author{
Diah Sri Rejeki ${ }^{1^{*}}$, Pawit M. Yusup ${ }^{1}$ \\ ${ }^{1}$ Universitas Padjadjaran, Indonesia \\ *e-mail: diahsr87@gmail.com
}

\begin{abstract}
Abstrak
Penelitian ini bertujuan untuk mengetahui wirausaha yang pernah dan sedang dilakukan oleh para ibu rumah tangga di Desa Sukamukti Kecamatan Ciamis. Langkah-langkah yang digunakan dalam penelitian ini adalah seleksi, provokasi, rekaman dan decoding. Hasil penelitian menjelaskan bahwa para ibu rumah tangga yang berkumpul dalam membentuk kelompok usaha, dimuali dari memiliki motivasi dan minat yang sama dalam membantu ekonomi keluarga. Salah satu hal yang dilakukan adalah menerima pesanan masakan lokal, membuat kue, membuat makanan ringan untuk anak-anak, dan sebagainya. Hal yang menarik dari kelompok usaha tersebut adalah para ibu rumah tangga mendapatkan inspirasi, informasi dan pengetahuan tentang kewirausahaan melalui internet dengan media handphone. Informasi yang paling sering dicari dan dibaca adalah mengenai resep, kisah sukses pengusaha, dan teori pemasaran baik offline atau online. Kesimpulannya bahwa pengalaman wirausaha para ibu rumah tangga melalui kelompok usaha "Dewi Catering" berkaitan dengan membaca melalui media handphone yang menggunakan jaringan internet (membaca online). Adapun hasil yang diperoleh dari membaca online adalah ibu rumah tangga dapat memperkuat motivasi berwirausaha, dapat meningkatkan keterampilan memasak dan dapat memiliki keterampilan untuk memasarkan produk mereka.
\end{abstract}

Kata kunci: Wirausaha; Ibu Rumah Tangga; Membaca Online

\begin{abstract}
This study aims to determine the entrepreneurship that has been and is being carried out by housewives in Sukamukti Village, Ciamis District. The steps used in the research are selection, provocation, recording, and decoding. The study results explained that the housewives who gathered to form a business group started from having the same motivation and interest in helping the economy's family. One of the things to do is opening orders of local cuisine, making cakes, making snacks of children, etc. The business group's exciting thing is the housewife gets inspiration, information, and knowledge about entrepreneurship through the internet with mobile media. Information most sought and read about recipes, entrepreneur success stories, and marketing theories, either offline or online. The conclusion is the entrepreneurial experience of housewives through the "Dewi Catering" business group related to online reading results via the internet. The results obtained from reading online are housewives can strengthen entrepreneurial motivation, improve cooking skills, and have the skills to market their products.
\end{abstract}

Keywords: Entrepreneurship; Housewive; Online-Reading 


\section{PENDAHULUAN}

Desa Sukamukti secara geografis terletak di wilayah Kecamatan Pamarican Kabupaten Ciamis. Desa yang memiliki luas wilayah 388,713 hektar dengan luas lahan pertanian/sawah seluas 262,870 hektar atau 67,63 persen dari total luas wilayah desa, sehingga Desa Sukamukti bisa dikatakan sebagai Desa Agraris. ("Profil Desa Sukamukti," 2015). Desa agraris merupakan suatu desa yang penduduknya memiliki mata pencaharian utama di bidang pertanian dan perkebunan. Misalnya lahan pertanian banyak menghasilkan produk seperti padi, jagung, cengkeh, bawang sedangkan lahan perkebunan menghasilkan pepaya, kecambah, paria, tomat, pisang dan kelapa. Pertanian di Indonesia dihadapkan pada beberapa masalah seperti meningkatnya alih fungsi lahan, lemahnya daya saing kualitas dan harga pertanian, makin fluktuatifnya harga, pasokan, dan stok komoditas strategis, serta dampak perubahan iklim dan krisis ekologis. Data Badan Pusat Statistik tahun 2013 menjelaskan setiap tahun 80 ribu hektare lahan pertanian berubah fungsi menjadi lahan nonpertanian, salah satu penyebab utamanya adalah regulasi alih fungsi lahan tidak dijalankan secara ketat dan terkontrol, mulai dari tingkat pusat sampai ke daerah, sehingga mengakibatkan perkembangan sektor industri dan pemukiman tak terkendali, terutama di pulau Jawa. Akibat makin minimnya lahan pertanian, desa sebagai ujung tombak ketahanan pangan harus berpikir keras agar tetap bisa menghasilkan produk-produk pertanian dengan lahan yang terbatas. Salah satu desa yang memiliki potensi mengembangkan lahan pertanian menjadi produk pertanian adalah desa Sukamukti. Desa Sukamukti memiliki beberapa produk pertanian antara lain usaha kerupuk ampera, usaha konveksi, usaha pepaya california, usaha nata de coco, usaha sale pisang dan usaha kecambah.
Hasil produk desa biasanya dipasarkan langsung ke Pasar Banjarsari dan dijual ke tengkulak dengan harga murah. Sehingga menurut perhitungan ekonomi, para petani tersebut tidak mempunyai keuntungan yang banyak bahkan jika panennya serempak akan mengakibatkan para petani merugi. Seperti pada kasus panen tomat tahun lalu, petani menjual tomat dengan harga yang sangat murah kepada tengkulak, sehingga para petani merugi karena harus membayar biaya distribusi tomat tersebut. Di lain waktu ketika para petani tersebut mengalami panen serempak lagi, maka mereka sepakat untuk tidak menjual hasil panennya. Akibatnya para petani tidak mendapatkan hasil yang memadai dari kerja kerasnya selama bertani dan berkebun.

Ketika panen tidak mendapatkan hasil, para ibu rumah tangga di desa tersebut mencoba membantu para suami untuk mendapatkan nafkah tambahan. Salah satunya dengan berwirausaha. Menurut Kamus Besar Bahasa Indonesia (KBBI), pengertian wirausaha sama dengan wiraswasta, yaitu orang yang pandai atau berbakat mengenali produk baru, menentukan cara produksi baru, menyusun operasi untuk pengadaan produk baru, memasarkannya, serta mengatur permodalan operasinya. ("Kamus Besar Bahasa Indonesia (KBBI)," 2016). Mencari nafkah tambahan bagi seorang istri tidak harus pergi ke kantor setiap hari, bekerja di rumah pun bisa dilakukan. Misalnya, dengan membuka usaha yang diminati yaitu penjualan makanan ataupun barang-barang melalui online, membuka warung makan, membuka warung kelontong, dan lain-lain. (Ute Lies Siti Khadijah, 2016). Membuka usaha biasanya berawal dari kegemaran atau hobi. Misalnya, jika seseorang memiliki hobi membaca, maka dia bisa membuka taman bacaan ataupun jika seseorang memiliki hobi memasak, maka dia bisa membuka usaha menjual makanan. 
Berdasarkan penelitian yang dilakukan oleh Millennium Challenge Account-Indonesia dalam International Finance Corporation (2011), bahwa Sepertiga UKM di Indonesia dimiliki oleh perempuan. ("Perempuan dan Wirausaha," 2016). Artinya, perempuan masa kini sudah mencerminkan kemandirian dan memiliki kreatifitas. Perempuan yang mandiri, selain dapat menghasilkan uang tambahan juga akan mendapatkan kepuasan batin. Hal tersebut disebabkan karena pekerjaan yang dilakukan tanpa ada paksaan. Selama ini perkembangan wirausaha di Indonesia terus membaik Berdasarkan data Sakernas Agustus 2016, jumlah perempuan yang berprofesi sebagai wirausaha/pengusaha adalah 14,3 juta orang. Jumlah meningkat 1,6 juta orang dibandingkan tahun 2015 yang baru berjumlah 12,7 juta orang. Artinya makin banyak pengusaha-pengusaha, termasuk pengusaha perempuan yang tumbuh. Hal ini menunjukan bahwa perempuan telah semakin memperbesar perannya dalam perekonomian. ("Pemerintah Dorong Pertumbuhan Jumlah Wirausaha Perempuan Di Indonesia," 2017). Perkembangan zaman semakin menuntut partisipasi perempuan dalam membangun perekonomian rumah tangga. Berwirausaha juga merupakan bukti bahwa kaum perempuan mendukung kesetaraan gender. Semua pekerjaan dapat dilakukan oleh perempuan. Misalnya, perempuan yang menjadi sopir bus, kondektur, tukang parkir, tukang tambal ban, dan lain-lain. Bahkan, petugas Stasiun Pengisian Bahan Bakar untuk Umum (SPBU) yang semula didominasi laki-laki, saat ini melibatkan perempuan sebagai operator. Makin banyak perempuan yang mulai menyadari bahwa menjadi wirausahawan merupakan cara terbaik untuk membantu ekonomi keluarga. Terlebih, saat ini perempuan dan bisnis dapat berjalan beriringan, karena perempuan memiliki gaya bisnis yang berbeda dari kaum laki-laki. Perempuan lebih memilih bisnis yang berada pada lingkup keseharian, menggunakan perasaan, cenderung personal, bahkan melakukan aktivitas usaha yang berada di sela-sela rutinitas mengurus keluarga. Dengan pola pikirnya, perempuan berbisnis bukan untuk memperkaya diri, melainkan kesenangan hati dan minat pribadi. (Natalia Sari, 2017).

Perempuan yang berwirausaha dapat menjadi contoh yang baik bagi lingkungan keluarga ataupun lingkungan sosialnya. Adapun hal positif yang dapat diajarkan antara lain mengenai profesionalisme, aktualisasi diri, dan kesabaran serta hal-hal yang sifatnya psikologis. Selain itu perempuan dalam keluarga pun mempunyai peran penting dalam ikut membantu suami dalam meningkatkan ekonomi keluarga. Maka dari itu, Perempuan sudah seharusnya membekali diri dengan semangat untuk terus belajar. Mengikuti perkembangan teknologi, meningkatkan pendidikan, baik formal maupun nonformal, serta menambah pengetahuan dan keterampilan supaya mampu menjalankan peran ganda tersebut. Salah satunya melalui membaca.

Membaca adalah proses memahami pesan tertulis yang menggunakan bahasa tertentu yang disampaikan oleh penulis kepada pembacanya (Alex A dan H.P Ahmad, 2010). Melalui membaca para perempuan mendapatkan sejumlah informasi dan pengetahuan yang sangat berguna dalam praktik kehidupan seharihari. Misalnya pengetahuan mengenai keiwirausahaan, mulai dari tata cara membangun sebuah usaha kecil-kecilan, kisah sukses perempuan dalam berwirausaha, hambatan-hambatan dalam mendirikan usaha, dan sebagainya. Untuk saat ini, membaca dapat dilakukan kapanpun dan dimanapun dengan media yang mudah diakses. Misalnya melalui teknologi komunikasi dan informasi salah satunya internet. 
Kemajuan teknologi informasi dan komunikasi memungkinkan kita mengakses internet dengan menggunakan berbagai pilihan teknologi yang ada. Masing-masing teknologi dapat mengakses internet dengan berbagai cara, misalnya dengan handphone, laptop ataupun Personal Computer. Saat ini, jaringan internet pun sudah memasuki desa Sukamukti. Banyak masyarakat desa menggunakan internet hanya sekedar untuk komunikasi, mencari informasi, memainkan permainan online, dan sebagainya. Hal yang serupa dilakukan oleh perempuan khususnya Ibu Rumah Tangga dalam mencari informasi melalui jaringan internet dengan menggunakan media handphone.

Salah satu hal yang dilakukan oleh para ibu rumah tangga dalam membantu ekonomi keluarga yaitu membuka catering melalui kelompok usaha. Kelompok usaha ini dicetuskan oleh tim dosen Universitas Padjadjaran dengan membuat kegiatan pelatihan kewirausahaan melalui kegiatan Pengabdian Kepada Masyarakat. Desa Sukamukti memiliki 2 kelompok usaha yang terdiri antara 4-8 orang ibu rumah tangga. Kelompok usaha tersebut bernama "Wanita Mandiri" dan "Dewi Catering". Saat ini kelompok "Wanita Mandiri" sedang vakum dikarenakan ada permasalahan dalam kelompok usahanya. Hal tersebut sangat disayangkan mengingat kelompok usaha "Wanita Mandiri" sempat menghasilkan keuntungan yang besar dengan menjual kue-kue yang dititipkan di warung-warung kecil ataupun toko besar. Kelompok yang masih berjalan dan memiliki penambahan anggota yakni kelompok usaha "Dewi Catering". Internet mempunyai pengaruh yang besar terhadap kelompok usaha "Dewi Catering". Hal tersebut bisa terjadi karena mayoritas anggota kelompok tersebut memulai produksi hingga memasarkan hasil produknya melalui internet. Aktifitas yang dilakukan adalah membaca artikel-artikel yang mendukung kinerja mereka, seperti resep masakan, cara menyebarluaskan produk, makanan yang sedang digemari, dan lain-lain. Melalui membaca selain menambah wawasan dan pengetahuan, juga bisa menimbulkan gagasan yang mengandung peluang bisnis.

Terdapat beberapa contoh sukses pengusaha online di Indonesia yang mencapai omset hingga milyaran, salah satunya adalah Hendrik Tio, merupakan pendiri dan pemilik toko online yang sangat dikenal yakni Bhinneka.com. Situs tersebut merupakan salah satu website ecommerce terbesar di Indonesia. Pada awalnya, Hendrik Tio bersama beberapa rekan sejawatnya yaitu Nicholas, Johannes, Darsono, dan Tommy berencana untuk melirik potensi dunia internet sebagai media pemasaran produk-produk teknologi informasi yang mereka jual. Setelah diskusi yang cukup panjang, akhirnya ia memutuskan untuk total membuat sebuah webstore dengan nama Bhinneka.com sesuai dengan gerai toko nya yang bernama Bhinneka. Modal 100 juta rupiah pun digelontorkan untuk awal pengembangan website. Jumlah yang tidak sedikit tersebut digunakan oleh Hendrik untuk mempromosikan websitenya melalui Google. Dengan harapan akan dengan cepat menarik perhatian para pembeli masuk pada website nya, Hendrik pun tidak ragu lagi meski dana yang sangat besar tersebut harus dikeluarkan. Namun keuntungan besar yang ia idam-idamkan nampaknya tidak akan datang dengan cara yang mudah. Dalam masa perkembangannya, toko Bhinneka sempat beberapa kali mendapat kan masalah. Seperti contoh nya pengaruh krisis global yang pernah terjadi beberapa waktu lalu hingga masalah penipun transaksi kartu kredit yang makin marak di dunia ecommerce. Bahkan hingga Hendrik harus mengambil keputusan untuk menutup layanan pembelian melalui transaksi kartu kredit. Kesabaran pria kelahiran medan 
tersebut pun telah di uji. Dengan kesabaran dan ketekunannya untuk berinovasi, lambat laun Bhinneka telah mendapatkan perhatian dan kepercayaan dari para pengguna internet yang sedang mencari produkproduk teknologi informasi atau pun gadget. Hingga akhir nya webstore yang dulunya hanya dikunjungi sekitas 50 visitor perhari tersebut kini telah mendapat pengunjung lebih dari ratusan ribu visitor perhari. ("Hendrik Tio - Pendiri Bhinneka.com, Website Ecommerce Terbesar Di Indonesia," n.d.) Saat ini website Bhinneka merupakan salah satu situs yang paling banyak dikunjungi di Indonesia.

Berdasarkan paparan tersebut diatas, maka permasalahan yang akan diangkat dalam penelitian ini adalah Bagaimana pengalaman berwirausaha berbasis membaca online di kalangan ibu rumah tangga. Penelitian ini bertujuan untuk mengetahui wirausaha yang pernah dan sedang dilakukan oleh para ibu rumah tangga di Desa Sukamukti Kecamatan Ciamis. Selain itu, melalui tulisan ini penulis berharap dapat menjadi sumber ide bagi para ibu rumah tangga lainnya yang ingin membuka peluang usaha.

\section{METODE}

Metode yang digunakan dalam penelitian ini adalah observasi lapangan ke Desa Sukamukti di Kecamatan Banjarsari Kabupaten Ciamis, Jawa Barat. Observasi adalah mengumpulkan data atau keterangan yang harus dijalankan dengan melakukan usaha-usaha pengamatan secara langsung ke tempat yang akan diselidiki (Suharsimi, 2010). Adapun teknik pengambilan data yang digunakan adalah dengan melakukan pengamatan secara langsung mengenai kondisi dan situasi desa serta melakukan wawancara dengan para ibu rumah tangga yang memiliki usaha mandiri, pengurus desa serta masyarakat sekitar yang menjadi konsumen pada usaha milik ibu rumah tangga tersebut.
Weick (1976: 253) secara lebih dalam menyebutkan bahwa observasi memiliki tujuh karakteristik, yaitu:

1. Pemilihan (selection). Pemilihan subjek yang akan diamati, dalam hal ini penulis memilih Ibu Rumah Tangga yang memiliki wirausaha.

2. Pengubahan (provocation). Penulis boleh mengubah perilaku atau suasana tanpa menganggu kealamiahan. Dalam hal ini penulis mencoba mengubah perilaku Ibu Rumah Tangga dengan menggunakan pengaruh keteladanan seseorang. Misalnya penulis menginformasikan mengenai contohcontoh sukses pengusaha dlam menjalankan bisnisnya.

3. Pencatatan (recording). Aktivitas merekam kejadian-kejadian dengan menggunakan catatan lapangan, sistem kategori, dan metode-metode lainnya. Penulis melakukan pencatatan dengan cara merekam setiap situasi dan kondisi Ibu Rumah Tangga.

4. Pengkodean (encoding). Proses menyederhanakan catatan-catatan melalui metode reduksi data. Dalam hal ini penulis melakukan proses pemilihan data yang dianggap penting dan menjadi prioritas dalam penelitian ini. (Karl Weick, 1979)

Pada setiap langkah observasi yang dilakukan, penulis melakukan konfirmasi dengan cara diskusi dan wawancara dengan orang-orang terkait. Adapun teknik analisis data yang dilakukan adalah dengan cara membandingkan data satu dengan data yang lain, kemudian secara membandingkan kategori yang satu dengan kategori lainnya. Secara umum proses analisis datanya meliputi reduksi data, kategori data, sintesisasi, dan diakhiri dengan menyusun hipotesis kerja. (Moleong, 2017)

\section{HASIL DAN PEMBAHASAN}

Jurnal IImu Sosial dan Humaniora | 205 
Desa Sukamukti merupakan desa
agraris yang mayoritas mata pencahariannya adalah bertani dan berkebun. Desa tersebut memiliki beberapa produk pertanian antara lain usaha kerupuk ampera, usaha konveksi, usaha pepaya california, usaha nata de coco, usaha sale pisang dan usaha kecambah. Ketika panen tidak mendapatkan hasil, para ibu rumah tangga di desa tersebut mencoba membantu para suami untuk mendapatkan nafkah tambahan. Salah satunya dengan berwirausaha. Wirausaha yang dilakukan para ibu rumah tangga adalah dengan memaksimalkan keterampilan yang dimiliki dengan menggunakan modal yang minim.

Terdapat beberapa hasil penelitian mengenai wirausaha yang dilakukan oleh perempuan, yaitu: hasil penelitian mengenai Identifikasi Motivasi Wirausaha Perempuan Pedesaan Dengan Hadirnya Mitra Pembangun Berdasarkan Pendekatan Teori Harapan yang dilakukan oleh Teguh Endaryono menyatakan bahwa motivasi perempuan dalam berwirausaha adalah ingin menambah penghasilan, tidak bergantung pada orang lain, keleluasaan mengatur waktu, dan menambah aset keluarga. Wirausaha perempuan di pedesaan yang menjadi mitra bisnis termotivasi dengan adanya modal stimulus dari pihak kampus, terutama pada saat awal membuka bisnis. Wirausaha perempuan pedesaan juga akan termotivasi bila berhasil memiliki best practices yang tepat dengan usaha bisnisnya, mereka mendapat respon positif dari tetangga, dihormatinya prinsipprinsip dasar yang dianut dalam menjalankan bisnis serta keberhasilan dalam menambah aset keluarga. (Teguh Endaryono, 2016).

Hasil penelitian selanjutnya yang dilakukan oleh Silvia Sari, Wahyu Budi Priatna, dan Burhanuddin yang berjudul Pengaruh Aktivitas Wanita Wirausaha Terhadap Pertumbuhan Usaha Olahan Kentang Di Kabupaten Kerinci, Jambi yang menjelaskan bahwa Karakteristik kewirausahaan yang dimiliki wanita wirausaha di Kabupaten Kerinci dibentuk oleh motivasi $(\lambda=0.54)$, risiko $(\lambda=0.32)$, dan inovasi $(\lambda=0.95)$. Dengan demikian usaha dari wanita yang mengolah kentang di Kabupaten Kerinci adalah UMKM yang berkarakter wirausaha. Hasil analisis SEM menunjukkan bahwa aktivitas wanita wirausaha dipengaruhi paling besar oleh faktor eksternal ketersediaan sumberdaya $(\gamma=0.66)$ dan faktor internal karakteristik kewirausahaan $(y=0.59)$. Hal ini menunjukkan faktor internal dan eksternal sama-sama kuat mempengaruhi aktivitas wanita wirausaha. Aktivitas usaha wanita terbukti menumbuhkan usaha pengolahan kentang $(\beta=0.95)$. Sehingga wanita bisa menciptakan nilai tambah pada produk pertanian dan berperan dalam ekonomi Indonesia (Silvia Sari, Wahyu Budi Priatna, 2015).

Hasil penelitian lainnya yang berjudul Peran Perempuan Dalam Mengembangkan Enterpreneur/Wirausaha Kasus Di Kub Maju Makmur Kecamatan Kejajar Kabupaten Wonosobo yang dilakukan oleh Indah Widowati menyatakan bahwa kaum perempuan berhasil mengembangan wirausaha di KUB Maju Makmur dengan produk yang dihasilkanpun mampu dijual di berbagai daerah dengan harga yang kompetitif. Contoh usaha yang dilakukan adalah mengubah buah terong belanda menjadi sirup (Indah Widowati, 2012).

Perbedaan dengan penelitian yang dilakukan penulis adalah penulis menjelaskan pengalaman para ibu rumah tangga dalam melakukan wirausaha dengan modal keterampilan yang didapat dari membaca online melalui jaringan internet. $\mathrm{Di}$ zaman serba digital ini, belajar bisa dilakukan kapanpun, dimanapun dengan media apapun. Salah satu yang paling sering digunakan oleh para ibu rumah tangga Desa Sukamukti adalah membaca 
menggunakan handphone yang terhubung dengan jaringan internet.

\section{Kelompok Wirausaha Dewi Catering}

Para ibu rumah tangga yang berkumpul membentuk kelompok usaha, berawal dari memiliki motivasi dan minat yang sama yaitu membantu ekonomi keluarga. Salah satu hal yang dilakukan oleh para ibu rumah tangga dalam membantu ekonomi keluarga yaitu membuka pesanan masakan lokal, membuat kue-kue, membuat jajanan anakanak, dan lain-lain. Kelompok usaha ini dicetuskan oleh tim dosen Universitas Padjadjaran dengan membuat kegiatan pelatihan kewirausahaan melalui kegiatan Pengabdian Kepada Masyarakat. Desa Sukamukti memiliki 2 kelompok usaha yang terdiri antara 4-8 orang ibu rumah tangga. Kelompok usaha tersebut bernama "Wanita Mandiri" dan "Dewi Catering". Saat ini kelompok "Wanita Mandiri" sedang vakum dikarenakan ada permasalahan dalam kelompok usahanya. Hal tersebut sangat disayangkan mengingat kelompok usaha "Wanita Mandiri" sempat menghasilkan keuntungan yang besar dengan menjual kue-kue yang dititipkan di warung-warung kecil ataupun toko besar. Kelompok yang masih berjalan dan memiliki penambahan anggota yakni kelompok usaha "Dewi Catering". Kelompok usaha tersebut saat ini memiliki 10 anggota yang terdiri dari para ibu rumah tangga. Mayoritas suaminya bekerja sebagai petani dan buru serabutan di desanya, sehingga keadaan ekonomi keluarga tidak dapat mencukupi kebutuhan hidup sehari-hari. Para ibu rumah tangga tersebut memiliki tujuan yang sama yakni menghasilkan keuntungan dengan bekerja sesuai dengan keterampilan yang mereka miliki. Usaha yang pernah dijalankan yaitu menjual makanan lokal seperti mie ayam, seblak, cilok, bakso tahu, selain itu kelompok usaha tersebut juga menerima

\footnotetext{
${ }^{1}$ Narasumber Dewi, banjarsari 2017
}

pesanan masakan dengan skala besar. Internet mempunyai pengaruh yang besar terhadap kelompok usaha "Dewi Catering".

Hal menarik dari kelompok usaha tersebut adalah para ibu rumah tangga mendapatkan inspirasi, informasi dan pengetahuan mengenai kewirausahaan melalui internet dengan media handphone. Seperti yang diungkapkan oleh Dewi", "zaman sekarang mah gampang, nyari apa-apa di google. Dari mulai resep-resep zaman now sampe artikel-artikel serius". Informasi yang dicari dan dibaca mayoritas mengenai resep masakan, kisah sukses pengusaha, dan teori-teori mengenai pemasaran baik secara offline ataupun online. Berdasarkan hasil dari wawancara, mereka terkadang mempraktekan langsung apa yang pernah dibaca tanpa menyadari informasi tersebut bersifat sesat (hoax) atau tidak, sehingga hasil yang didapat kurang memuaskan. Namun mereka pantang menyerah, dengan mengimplementasikan konsep trial and error dalam proses pembelajarannya, para ibu rumah tangga pun berhasil mendapatkan keterampilan dalam memenuhi tujuan kelompok usaha.

Kelompok usaha tersebut mempunyai dua aktivitas besar yakni memasarkan produknya sesuai dengan permintaan pasar, dengan kata lain produk tersebut dibuat ketika ada pemesanan. Misalnya pemesanan paket nasi lengkap dengan dus untuk acara syukuran khitanan, pernikahan, ulang tahun dan syukuran lainnya. Aktivitas selanjutnya membuat jajanan lokal seprti kue-kue yang dititipkan di warung-warung, membuat kue lebaran ketika bulan Ramadhan datang, membuat jajanan lokal seperti mie ayam, bakso tahu dan seblak khusus setiap akhir pekan. Sejauh ini, kelompok usaha tersebut mempunyai uang kas yang diposisikan sebagai modal serta keuntungan-keuntungan yang dapat

Jurnal IImu Sosial dan Humaniora | 207 
dibagikan kepada para ibu rumah tangga yang berperan aktif.

Berdasarkan kuadran Bob Sadino, para ibu rumah tangga berada di posisi kuadran Bisa, yakni mereka belajar berwirausaha dari pengalaman dan lingkungan sekitar. Mereka tidak belajar teori di lembaga formal, namun mereka belajar secara otodidak melalui membaca online di internet.

\section{Peran Internet dalam Kelompok Usaha "Dewi Catering"}

Internet mempunyai peran yang

besar dalam kemajuan kelompok usaha "Dewi Catering". Selain menyediakan ilmu wirausaha yang bersifat gratis, dengan internet kelompok usaha tersebut dapat membuka peluang kerjasama dengan wirausahawan lainnya. Seperti yang dilakukan oleh kelompok usaha tersebut, manfaat internet dapat dimanfaatkan dengan maksimal seperti yang terdapat pada Gambar 1.

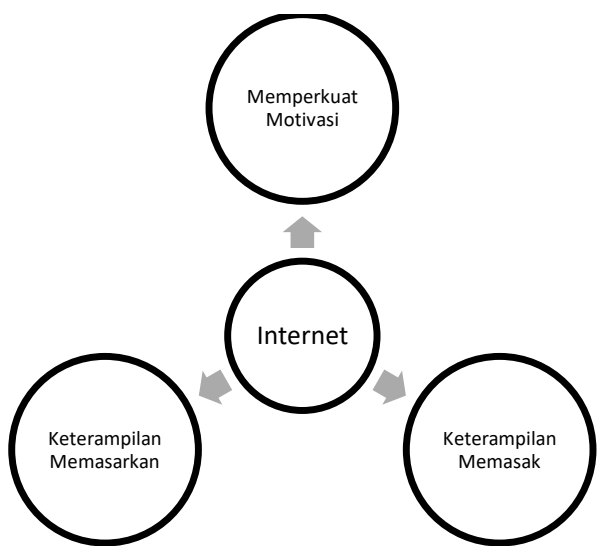

Gambar 1. Peran Internet dalam Kelompok Usaha "Dewi Catering"

Internet sejatinya dapat dimanfaatkan dalam berbagai bidang, misalnya pendidikan, kesehatan pemerintahan dan dunia wirausaha. Kelompok usaha Dewi Catering memaksimalkan manfaat internet untuk beberapa tujuan, yakni:
1. Memperkuat motivasi. Para ibu rumah tangga dalam kelompok usaha tersebut memiliki tujuan yang sama, yaitu mendapatkan keuntungan untuk membantu meningkatkan ekonomi keluarga. Ketika usaha yang dijalankan tidak sesuai dengan harapan, terkadang mereka menjadi down dan tidak punya gairah atau semangat untuk meneruskan kelompok usaha tersebut. Namun ada beberapa anggota kelompok usaha, yang selalu berfikiran positif dengan cara mencari informasi mengenai sepak terjang pengusaha sukses di internet. Lalu anggota yang mendapatkan informasi tersebut, memberitahukan kepada anggota lainnya dengan cara ngobrol santai ketika sore hari, ataupun melakukan berbagi informasi melalui Grup Whatsapp.

2. Meningkatkan keterampilan memasak. Memasak merupakan kemampuan praktik yang perlu dilakukan berulangulang hingga mendapatkan rasa yang diharapkan. Awalnya para ibu rumah tangga dalam kelompok usaha tersebut tidak bisa membuat kue lebaran kekinian, mereka hanya membuat kue tradisional khas Desa Sukamukti yang ilmunya diperoleh turun temurun dari para leluhur mereka. Misalnya sale pisang, puyum (tape ketan), jenang (dodol jawa), dan lain-lain. Namun permintaan pasar saat ini menginginkan kue lebaran yang dapat dimasukan ke dalam toples cantik, seperti yang mereka lihat di iklan televisi, misalnya kue nastar, putri salju, black forrest, kastengel, dan lain-lain. Melalui internet kelompok usaha tersebut mencari informasi seputar resep masakan sesuai dengan permintaan pasar. Di awal mereka pernah gagal dalam membuat kue-kue tersebut, namun seiring banyaknya 
latihan mereka pun akhirnya dapat membuat kue seprti yang diinginkan. Untuk mencari resep masakan yang sesuai di internet pun tidaklah mudah, karena banyaknya beredar resep-resep palsu (kurang bahan makanan, kurang langkah proses memasak, dan lain-lain), untuk menyiasati hal tersebut maka mereka mengimplementasikan konsep trial and error hingga mendapatkan apa yang diharapkan.

3. Keterampilan memasarkan. Awalnya kelompok usaha tersebut memasarkan produknya dengan jangkauan terdekat, misalnya menitipkan makanan di warung-warung di desa tersebut. Namun, hasil yang didapat belum maksimal, sehingga mereka mencari cara melalui internet untuk proses pemasaran yang lebih efektif dan efisien. Caranya adalah pemasaran melalui online. Para ibu rumah tangga memanfaatkan Facebook sebagai sarana utama dalam kegiatan promosi. Dalam facebook tersebut berisi foto-foto makanan yang bisa dipesan, testimonial dari teman-teman yang pernah mencoba dan nomor kontak yang dapat dihubungi. Untuk lebih menarik minat pasar, kelompok usaha ini membuat konsep pesanan layan antar secara gratis untuk daerah-daerah yang berjarak dekat dengan rumah produksi.Dengan menggunakan pemasaran secara online, kelompok usaha tersebut memiliki peningkatan keuntungan yang drastis dibandingkan dengan pemasaran offline.

Internet dalam era digital ini memiliki banyak manfaat dalam dunia wirausaha, misalnya dapat mempermudah akses penjualan sehingga pasar yang awalnya tidak tahu keberadaan kelompok usaha "Dewi Catering" menjadi tahu bahkan menjadi pelanggan tetap. Manfaat selanjutnya dapat mempermudah komunikasi jarak jauh, jika pasar ingin memesan produk, maka tidak perlu datang ke rumah produksi, cukup dengan memesan melalui facebook atau menghubungi nomor kontak yang tertera. Manfaat lain dari internet yaitu lebih mudah berkembang dan mendapatkan lebih banyak pelanggan, karena para ibu rumah tangga dapat dengan mudah memperoleh informasi yang berkaitan dengan pemesanan, serta mempermudah pelanggan dalam bertransaksi.

\section{Berwirausaha melalui membaca online}

Membaca merupakan kegiatan merespon lambang-lambang tulisan dengan menggunakan pengertian yang tepat (Farboy, 2014). Artinya melalui membaca, pola pikir dapat terasah sehingga akan meninbulkan pemahaman yang kritis terhadap suatu objek. Sama seperti halnya dengan membaca online, yang membedakan membaca online dengan offline adalah media yang digunakan. Membaca online merupakan membaca dengan menggunakan media komunikasi yang berjaringan internet atau biasa disebut online. Bahan bacaan online pun tersebar dengan luas dan tidak terbatas, misalnya bacaan dalam bentuk ebooks, ejournal, emagazine, enews, ataupun situs-situs lain yang menyediakan sumber informasi.

Kelebihan dari membaca online antara lain: (1) dapat dilakukan dimana saja sehingga dapat menyesuaikan dengan kesibukan yang dimiliki, (2) dapat dilakukan kapan saja tanpa agenda waktu tertentu, dan (3) Buku yang dibaca secara online dapat disimpan dalam memory handphone sehingga tidak membutuhkan ruangan untuk menyimpan buku tersebut (tidak seperti buku fisik yang membutuhkan ruangan). Seperti yang diungkapkan oleh salah satu narasumber Kelompok Usaha Dewi Catering yang bernama Mujirah: "membaca online ga repot, mudah nyari informasi yang 
kita mau, kalaupun informasinya tidak pas, ya cari artikel lain". Membaca online lebih disukai daripada membaca buku teks karena narasumber dapat dengan mudah memilih artikel yang sesuai dengan keinginan.

Berdasarkan hasil wawancara dan observasi, langkah-langkah membaca online versi ibu rumah tangga yang tergabung dalam kelompok usaha Dewi Catering adalah sebagai berikut. Hal pertama yang dilakukan dalam kegiatan membaca online adalah membuka mesin pencari dalam handphone. Berdasarkan hasil wawancara, Mayoritas mesin pencari yang digunakan oleh para ibu rumah tangga adalah google dengan menggunakan browser chrome ataupun internet explorer. Para ibu rumah tangga mengetahui internet melalui anaknya yang sudah sekolah, ataupun suaminya yang sedikit tidak gagap terhadap teknologi. Google merupakan salah satu mesin pencari yang sangat populer, padahal masih banyak mesin pencari lainnya yang terdaftar. Jenis search engine dapat dikelompokkan menjadi 4 bagian, yakni (1) Crawler-Based Search Engine. Layanan mesin pencari ini menggunakan program software otomatis untuk mengkategorikan banyak laman web. Ketika pengguna internet melakukan pencarian, mesin pencari segera memriksa database dari laman website yang mengandung kata kunci spesifik lalu menampilkan dalam bentuk daftar tautan (link). Daftar tautan berisi kata kunci terdekat yang pengguna internet tuliskan. Adapun contohnya yaitu google dan ask jeeves. (2) Direktori. Layanan ini menggunakan editor manual atau keterlibatan langsung manusia untuk menentukan kategori suatu situs. Ada dua layanan yang terkenal yaitu yahoo directory dan open directory (dmoz.org). (3) Hybrid Seacrh Engine, merupakan kombinasi sempurna antara crwal-based

\footnotetext{
2 Narasumber Sri Sujatmi, Banjarsari 2017
}

dan direktori. Layanan yang dikenal sebagai pencetusnya adalah google dan yahoo ("Pengertian Search Engine, Manfaat serta Jenis Search Engine," n.d.).

Langkah selanjutnya adalah memasukan kata kunci yang diinginkan. Dalam tahap ini para ibu rumah tangga tidak menggunakan kata kunci sederhana, namun mereka menuliskan dengan kalimat lengkap. Seperti yang disampaikan oleh Sri Sujatmi $^{2}$ ketika sedang browsing mencari artikel mengenai pengusaha sukses, "tinggal ketik aja.. pengusaha kecil jadi sukses dengan modal kecil... nanti bakalan muncul banyak artikel'. Saat ini teknologi sudah semakin canggih sehingga kalimat apapun yang akan dimasukan dalam kata kunci, tetap akan terbaca oleh google search engine. Strategi pencarian informasi pada search engine, tentunya akan lebih memudahkan pengguna dalam mencari informasi yang diinginkan. Strategi tersebut antara lain: (1) Boolean logic yang dikenal dengan penggunaan kata and, or, not dalam penelusuran informasi, (2) Phrase search yakni penggunaan beberapa kata agar tidak dicari secara terpisah dengan menggunakan tanda "....", (3) Permainan query lainnya seperti, mencari kata dengan sinonimnya menggunakan tanda , mencari karakter pengganti kata menggunakan tanda *, dan sebagainya.

Setelah menuliskan kata kunci yang diinginkan, maka muncul daftar tautan yang tidak terbatas, para ibu rumah tangga pun memilih tautan dengan cara klik tautan tersebut, sehingga artikel yang diinginkan pun muncul. Jika artikel yang di klik tidak sesuai dengan yang diinginkan, maka mereka mencari artikel lain ataupun mengubah kata kunci. Namun jika artikel tersebut adalah sesuatu yang diinginkan, maka mereka menyimpannya dengan klik bookmarks pada laman website tersebut. Seperti yang diungkapkan oleh Dewi $^{3}$

\footnotetext{
${ }^{3}$ Narasumber Dewi, Banjarsari 2017
}

Jurnal IImu Sosial dan Humaniora | 210 
bahwa: "saya mah sukanya artikel itu disimpen dulu, jadi kapan-kapan kalo lupa bisa dibaca lagi". Keunggulan dari membaca online adalah mudah melakukan pencarian dan dapat menyimpan laman tersebut sehingga sewaktu-waktu dapat digunakan kembali.

\section{SIMPULAN DAN SARAN}

Pengalaman berwirausaha yang dilakukan para ibu rumah tangga melalui kelompok usaha "Dewi Catering" berkaitan dengan hasil membaca online melalui internet. Hasil yang didapat dari membaca online tersebut adalah para ibu rumah tangga dapat memperkuat motivasi berwirausaha, dapat meningkatkan keterampilan memasak dan dapat memiliki keterampilan memasarkan produknya.

\section{DAFTAR PUSTAKA}

Alex A Dan H.P Ahmad. (2010). Bahasa Indonesia Untuk Perguruan Tinggi. Jakarta: Kencana.

Desi Aditia Ningrum. (2017, November 23). Ini Daftar Merek Paling Inovatif Yang Menjadi "Pertama Di Indonesia" Tahun 2017. Merdeka.Com. Retrieved From Https://Www.Merdeka.Com/Uang/IniDaftar-Merek-Paling-Inovatif-YangMenjadi-Pertama-Di-IndonesiaTahun-2017.Html

Farboy, S. (2014). Penerapan Metode Cooperative Integrated Reading And Composition (Circ) Untuk Meningkatkan Kemampuan Menemukan Gagasan Utama Sebuah Teks Pada Siswa Kelas Vii Di Smp Negeri 3 Batu Tahun Ajaran 2008/2009. Jurnal Artikulasi, 7(1), 415-431. Retrieved From File:///C:/Users/Acer Es1432/Downloads/1279-2860-2-Pb.Pdf

Hana Wisteria. (2016). Bob Sadino: Goblok Pangkal Kaya. Yogyakarta: Genesis Learning.
Hendrik Tio - Pendiri Bhinneka.Com, Website Ecommerce Terbesar Di Indonesia. (N.D.). Retrieved September 5, 2017, From Https://Www.Maxmanroe.Com/Hendri k-Tio-Pendiri-Bhinneka-Com-WebsiteEcommerce-Terbesar-DiIndonesia.Html

Indah Widowati. (2012). Peran Perempuan Dalam Mengembangkan Enterpreneur/Wirausaha Kasus Di Kub Maju Makmur Kec. Kejajar Kab. Wonosobo. In Bussines Conference. Yogyakarta: Upn Veteran. Retrieved From

Http://Repository.Upnyk.Ac.Id/4852/2/ 9 Indah_Agribisnisupnyk.Pdf

Kamus Besar Bahasa Indonesia (Kbbi). (2016). Retrieved From Http://Kbbi.Web.Id/Usaha

Karl Weick. (1979). The Social Psychology Of Organizing. Ma: Addison-Wesley.

Moleong, L. J. (2017). Metode Penelitian Kualitatif. Bandung: Remaja Rosdakarya.

Natalia Sari. (2017). Teladan Positif Dari Perempuan Berwirausaha. Retrieved October 3, 2017, From Http://Prakarsa-Jatim.Com/TeladanPositif-Dari-Perempuan-

Berwirausaha/

Ning Rahayu. (2017, October 11). Ini 9 Prinsip Gila Bob Sadino Yang Membuatnya Kaya Raya. Wartaekonomi. Retrieved From Https://Www.Wartaekonomi.Co.Id/Re ad157367/Ini-9-Prinsip-Gila-BobSadino-Yang-Membuatnya-KayaRaya.Html

Pemerintah Dorong Pertumbuhan Jumlah Wirausaha Perempuan Di Indonesia. (2017, May 16). Http://Biz.Kompas.Com. Retrieved From

Http://Biz.Kompas.Com/Read/2017/05 /16/093800628/Pemerintah.Dorong.P ertumbuhan.Jumlah.Wirausaha.Pere 
mpuan.Di.Indonesia

Pengertian Search Engine, Manfaat Serta Jenis Search Engine. (N.D.). Retrieved July 13, 2018, From Https://Seon.Co.Id/Pengertian-

Search-Engine-Manfaat-Dan-JenisJenis-Search-Engine/

Perempuan Dan Wirausaha. (2016). Retrieved From Http://Www.McaIndonesia.Go.Id/Assets/Uploads/Medi a/Pdf/Factsheet_Sga-Ind-Mail.Pdf

Profil Desa Sukamukti. (2015). Retrieved From Https://Kknm.Unpad.Ac.Id/Sukamuktic iamis/Profil-Desa/

Rahman Zailani Kiki. (2015). Bob Sadino, Sarjana Dan Jic 7mix. Retrieved April 18, 2018, From Http://Www.Republika.Co.Id/Berita/Ga ya-

Hidup/Trend/14/10/08/Koran/NewsUpdate/15/02/09/Njhq0935-BobSadino-Sarjana-Dan-Jic-7mix

Retno Dewanti. (2008). Kewirausahaan. Jakarta: Mitra Wacana Media.

Silvia Sari, Wahyu Budi Priatna, Dan B. (2015). Pengaruh Aktivitas Wanita Wirausaha Terhadap Pertumbuhan Usaha Olahan Kentang Di Kabupaten Kerinci,

Jambi. Agribisnis Indonesia, 3(1), 39-54. Retrieved From Https://Media.Neliti.Com/Media/Public ations/73262-Id-Pengaruh-AktivitasWanita-Wirausaha-Terh.Pdf

Suharsimi, A. (2010). Prosedur Penelitian: Suatu Pendekatan Praktek. Jakarta: Rineka Cipta.

Teguh Endaryono. (2016). Identifikasi Motivasi Wirausaha Perempuan Pedesaan Dengan Hadirnya Mitra Pembangun Berdasarkan Pendekatan Teori Harapan. Matrik: Jurnal Manajemen, Strategi Bisnis Dan Kewirausahaan, 10(2), 179-189. Retrieved From Http://Download.Portalgaruda.Org/Arti
cle.Php? Article $=457779 \&$ Val $=954 \&$ Titl e=Identifikasi Motivasi Wirausaha Perempuan Pedesaan Dengan Hadirnya Mitra Pembangun Berdasarkan Pendekatan Teori Harapan

Ute Lies Siti Khadijah. (2016). Literasi Informasi Motivasi Berwirausaha lbu Rumah Tangga Kelurahan Nagasari Kabupaten Karawang Barat. Jurnal Kajian IImu Informasi Dan Perpustakaan, 4(2), 150. Retrieved From Http://Jurnal.Unpad.Ac.Id/Jkip/Article/ View/8491/4796

Yuyus Suryana Dan Bayu Kartib. (2011). Kewirausahaan Pendekatan Karakteristrik Wirausaha Sukses. Jakarta: Kencana. 